\title{
Hahn and Miller share plans for ACRL
}

\author{
By Bessie K. Hahn and William Miller
}

\section{Be sure to vote in the election this spring}

$\mathbf{E}$ d. note: CERL News offered ACRL candidates for vice-president/president-elect, Bessie K. Hahn and William Miller, this opportunity to share their views with the ACRL membership. Although many of the issues and concerns facing ACRL are discussed informally at meetings, this does not provide a national forum available to all members. We hope that providing this forum will assist you in making an informed choice when you receive your ballot next month.

\section{BESSIE K. HAHN}

The ACRL Board and Planning Committee are developing a new strategic plan for the association with a projected date of completion by mid-1995. The new plan will generate a set of goals and objectives which I, if elected, will strongly support. In the meantime, taking advantage of many initiatives already begun by recent presidents, I have in mind several key issues that I hope to have the chance to address.

\section{Service to members}

The first and foremost task of ACRL is to help its membership grow and flourish as academic librarians. The 1993 ACRL member survey indicated that the top two reasons for membership in ACRL are to update knowledge of library practices and to be professionally involved. Academic librarians are concerned about keeping current with technological advances and having access to electronic com-

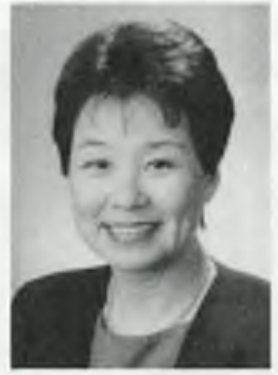

Bessie K. Hahn

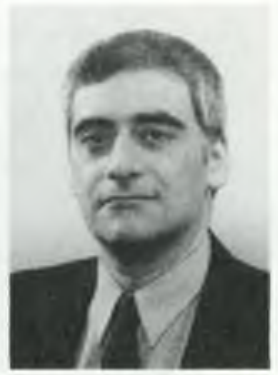

William Miller munication. They want to assist faculty and students in using information resources most effectively. ACRL has been successful in fulfilling the needs of its members in the past. However, as the pace of change accelerates in our libraries, as demands for services overtax our human resources, and as library budgets continue to tighten, we must look for new ways for our members to share their technological, collection development, teaching, and other expertise.

Another important staff development area is the way we interact with each other in an organizational setting. The traditional organizational structures of academic libraries are hierarchical and divisional by specific functions. In a turbulent, exciting environment, the hierarchical structure often hinders creativity and timely response to challenges. Technology has also imposed common electronic threads upon all library functions. The lines separating divisions-for example, collection management and reference-are much less defined. In our search for more efficient and productive models of organizational structure, the terms most often mentioned are: "team-management," "self-man- 

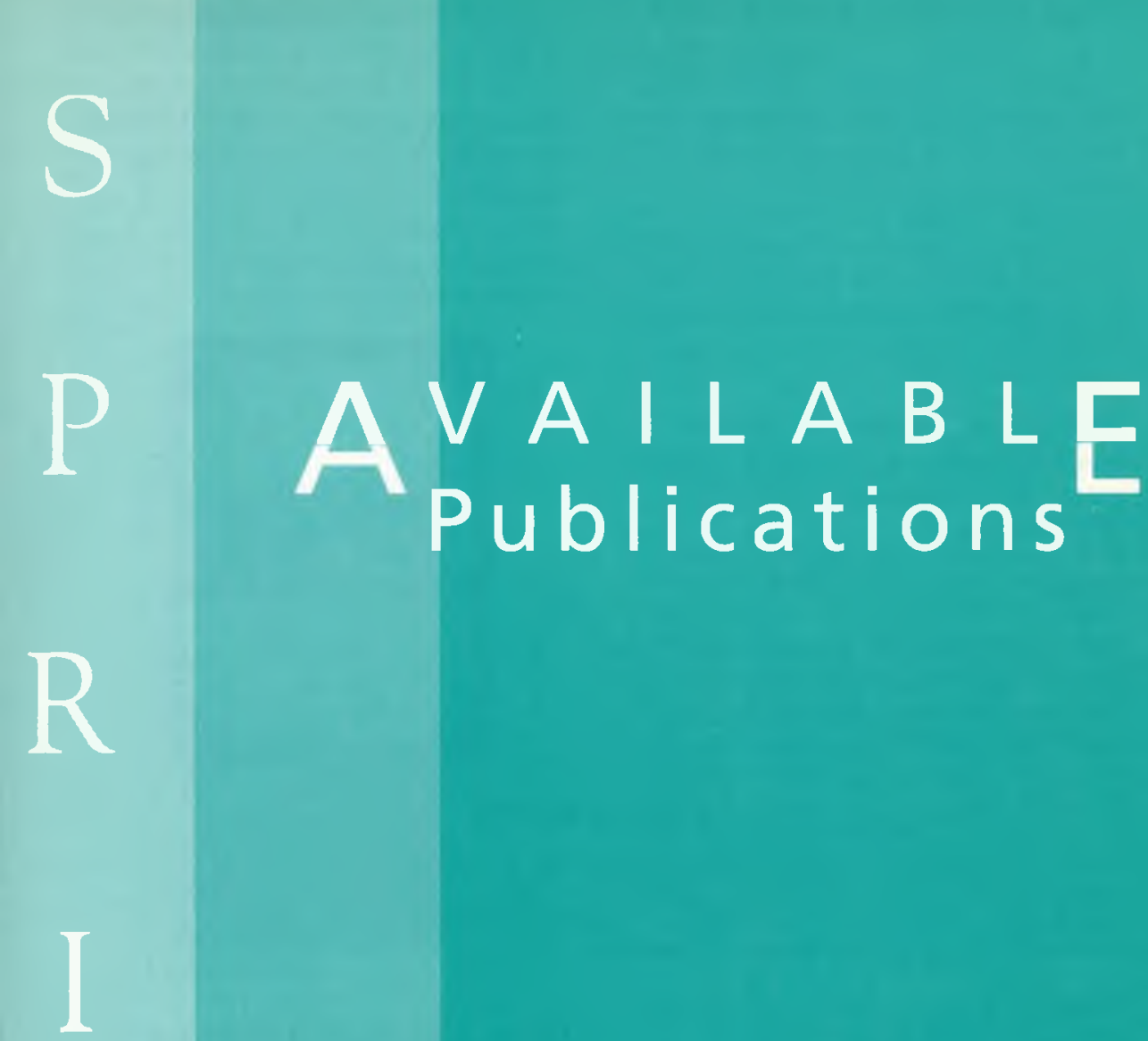

N

$\frac{\text { A C R L L }}{\text { Association of College }}$ 1995
(6) Research Libraries 


\section{MANAGEMENT}

\section{Preparing for Accreditation: A}

Handbook for Academic Librarians

Paricia Ann Sacks and

Sara Lou Whildin

This valuable, step-by-step workbook helps

librarians complete their self-study and

evaluation processes.

$\$ 18.00,80 p$.

0-8389-0621-4, 1993

\section{Measuring Academic Library}

Performance: A Practical Approach

Nancy Van House, Beth Weil, and

Charles Mcclure

This easy-to-use set of output measures is designed to assist in measuring the impact, efficiency, and effectiveness of academic library activities.

$\$ 34.00,140$ p., 0-8389-0529-3, 1990;

$\$ 75.00$ with self-running database,

0-8389-0542-0, 1991
Recruiting the Academic Library

Director: A Companion to the Search

Committee Handbook

Sharon Rogers and Ruth Person

\$18.95; ACRL member $\$ 15.95$

$0-8389-7484-8,1991$

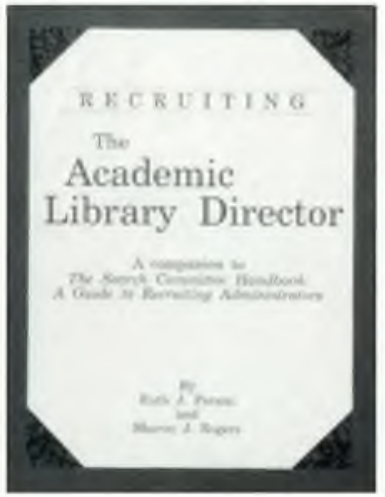

\section{CLIP Noles}

Practical icleas for managing your library's programs and services are contained in ACRL's College Library Information Packets (CLIP Notes). Each CLIP Note provides data and sample documents from college and small university libraries that will assist you in establishing or refining services and operations.

\section{NEW!}

\section{Library Services for Non-} Affiliated Patrons, CLIP Note \#21

Eugene S. Mitchell. comp.

Sample

policies and procedures for clealing with service to the nonaffiliated library user. Collected from acaclemic institutions nationally Inclucles examples of information

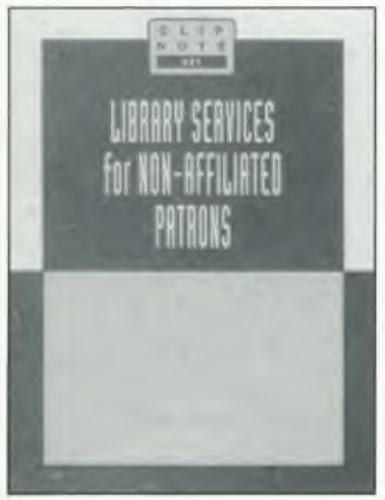
sheets.

application and registration forms, ID) cards, recourse letters, and reciprocal agrecments. $\$ 32.95$; ACRL member $\$ 27.95,151 p$.

0-8389-7781-2, 1995

\section{Managing Student Workers in} College Libraries, CLIP Note \#20 Michael Kathman, Jane McGum Katbman. comps.

Comprehensive guiclance for managing stuclent employees. Inchucles examples of policies and procedures for employment, dismissal, orientation, training, supervision. and performance review. "Highly recommended for small and medium-sized libraries employing student workers."Library Joumal

$\$ 29.95$; ACRL member $\$ 25.95,140 p$. $0-8389-7752-9,1994$

\section{Formal Planning in College} Libraries, CLIP Note \#19

Sarah Watstein, Pamela Wonsek. Paula Mattheus, comps.

A survey of formal planning procedures at academic libraries. Includes examples of worksheets and checklists, vision statements, and formal planning documents.

$\$ 27.95$; ACRL member $\$ 24.95,120 p$. 0-8389-7743-X 


\section{Staff Development and Continu-} ing Education, CLIP Note \# 18

Elizabeth Sudduth, Lynn Livingston. comps.

Survey and examples of policies for development and continuing education of both professionals and paraprofessionals.

Sample documents are from development plans specifically for library personnel and from collegewide faculty clevelopment plans.

$\$ 22.95$; ACRL member $\$ 19.95,134 p$. 0-8389-7715-4, 1994

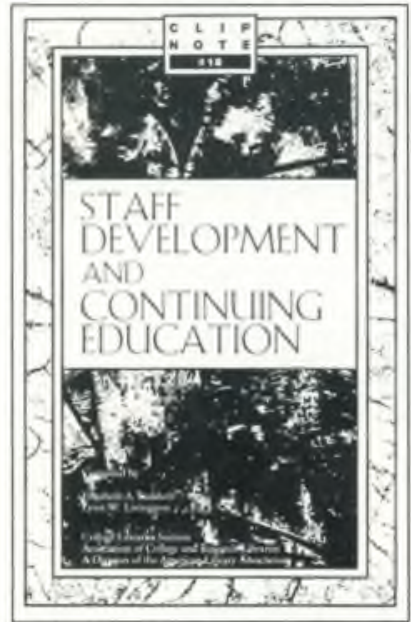

\section{Emergency Planning and Man- agement in College Libraries, CLIP Note \#17}

Susan C. George, comp

Policies and procedures for emergency planning and management in college libraries. Includes examples of plans covering everything from earthquakes to salvage proceclures.

$\$ 28.95$; ACRL member $\$ 25.95,146 p$. 0.8389-7710-3, 1994

\section{Interlibrary Loan in College Libraries, CLIP Note \#16}

Roxann Bustos, comp.

Sample policies and procedure statements. forms, public relations documents, and instructional handouts for libraries offering online searching, CD-ROM, and other computer-based services.

$\$ 34.50$; ACRL member $\$ 28.75,148 p$.

0-8389-7652-2, 1993

\section{Database Searching in College} Libraries, CLIP Note \#15

Sarah Pederson, uriter and comp

Samples of policies and procedures

statements, forms, promotional documents, and instructional handouts.

$\$ 29.95$; ACRL member $\$ 24.95,123 p$.

0-8389-7651-4, 1993

\section{Audiovisual Policies in College \\ Libraries, CLIP Note \# 14}

Kristine Brancolini, comp.

"The documentation included in the $k$ it is clear and of good cuality and covers all aspects of establishing and managing an audiovisual collection."-LRTS

$\$ 21.95$; ACRL member \$18.95, 152p. 0-8389-7495-3, 1991

\section{College Library Newsletters,} CLIP Note \#13

Patricia Smith Butcher and Susan

McCarthy Campbell. comps.

Sample newsletters as well as nameplates. graphics, and style manuals/guidelines for guest editors are inclucled.

\$18.95; ACRL member \$15.95, 154p. 0-8389-7445-7, 1990

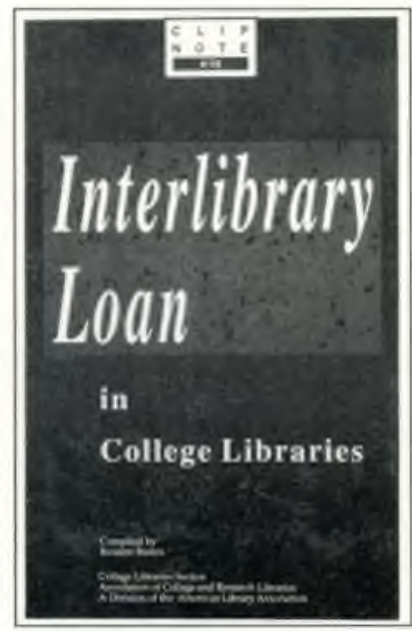




\section{Performance Appraisal in} Academic Libraries, CLIP Note \#12 Barbara Williams Jenkins, comp., with the assistance of Mary L. Smalls

-... a wicle variety of philosophies and approaches, ranging from series of relatively open-encled questions to grids for grading employees on specific qualities and achievements."-IAL

\$18.95; ACRL member \$15.95, 128p.

$0-8389-7444-9,1990$

\section{Collection Development} Policies for College Libraries, CLIP Note \# 11

Theresa Taborsky, comp.

". . this volume is well worth the price."

-Library Joumal

\$26.95; ACRL member $\$ 21.95,175 \mathrm{p}$.

0-8389-7295-0, 1989

\section{Annual Reports for College}

Libraries, CLIP Note \#10

Kenneth Oberembt, comp.

$\$ 21.95$; ACRL member \$18.75, 135p.

0-8389-7219-5, 1988

\section{Friends of College Libraries,} CLIP Note \#9

Ronelle Thompson, comp.

"This is a must for two groups of libraries those who have Friends groups and those who do not."-Library Joumal

\$18.75; ACRL member \$15.50, 134p.

0-8389-7171-7, 1987

\section{Periodicals in College Libraries, CLIP Note \#8}

Jamie Webster Hastreiter, Larry

Hardesty, David Henderson, comps.

"Recommended for all college and university libraries."-Library Joumal

\$18.75; ACRL member \$15.45, $116 \mathrm{p}$

0-8389-71 43-1, 1987

\section{Mission Statements for College Libraries, CLIP Note \#5}

Jamie Webster Hastreiter, Larry

Hardesty, David Henderson, comps.

". . a commendable production." $-R Q$

\$21.95; ACRL member \$16.50, 107p

0-8389-6944-5, 1985

\section{PERSONNEL ISSUES}

\section{NEW!}

\section{Discovering Librarians: Profiles of a Profession}

Mary Jane Scherdin, editor

Results of national studies of vocational interests of library and information professionals. The librarian profile is presented from the $\mathrm{ACT}$, the Strong Interest Inventories, the Myers-Briggs Type Indicator, and the SIGI PLUS computer-aided career guidance tool, along with analysis of demographic clata.

$\$ 35.95$; ACRL member \$31.95, 220p 0-8389-7753-7, 1994

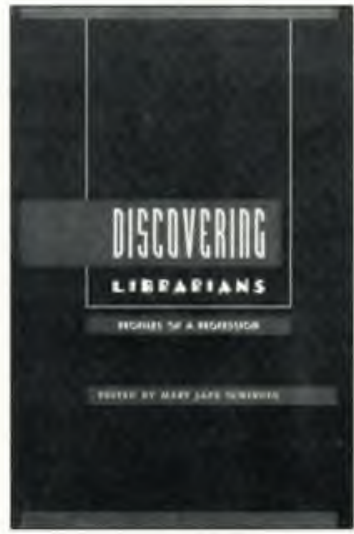

\section{Academic Status: Statements} and Resources, Second Edition Susan Kroll, editor

A compiliation of the ACRL standards and guiclelines that apply to faculty status for academic librarians, as well as a selective bibliography.

$\$ 10.95$; ACRL member $\$ 8.95,62 \mathrm{p}$.

0-8389-7739-1 


\section{COLLECTION DEVELOPMENT}

\section{Collection Managment in the} Electronic Age: A Manual for Creating Community College Collection Development Policy Statements Jennie S. Boyarski. Kate Hickey, editors A survey of community and junior colleges' collection development policies with examples of eleven complete and seven partial policy statements. $\$ 42.95$; ACRL member $\$ 35.95,197 \mathrm{p}$. 0-8389-7737-5, 1994

\section{Richard Garnett: The Scholar and Librarian Publications in Librarianship No. 46 \\ Barbara McCrimmin}

This is a "straightforward and wellresearched ... enjobable biogralphy—both interesting and readable."-Wilson Library Bulletin

$\$ 30.00,211 \mathrm{p}$.

0-8389-0508-0, 1989

\section{Curriculum Materials Center Collection Development Policy, Second Edition}

Beth G. Anderson, Virginia Nordstrom, Karin Duran, Allison G. Kaplan, comps.

A model policy is provided along with example policies from libraries that illustrate modifications to the model to fit specific local needs.

\$16.95; ACRL member \$14.95, 46p. 0-8389-7707-3, 1993

\section{Books for College Libraries III}

This set covers more than 50,000 titles chosen to represent a core collection of books for four-year college and university libraries. $B C L 3$ is also available on machine-readable tape. Contact ACRL. "Highly recommended."-Library Journal. $\$ 600 / 6$ vol. set, $\$ 125$ individual volume 0-8389-3353-X, 1988

\section{Directory of Curriculum Materials Center, 1990}

Donald Osier, Carol Wright, Janet Laurence, Mary Ellen Collins, Beth Anderson, comps.

This directory includes 272 institutions and covers purpose, hours, staffing, budget, service, and holdings.

$\$ 39.50$; ACRL member $\$ 32.95,240 p$ 0-8389-7439-2, 1991

\section{Women's Studies Collection Development Policies}

The WSS Collection Development and Bibliography Committee

This unique tool identifies issues and provicles models of existing policies. Complete policy statements from 16 university libraries illustrate the range of issues and provide a variety of models. The RLG Conspectus; Women's Studies supplemental guideline, included as an appendix identifies issues unique to women's studies and describes materials and sources.

$\$ 35.95$; ACRL member $\$ 29.95,122 p$. 0-8389-7596-8, 1992

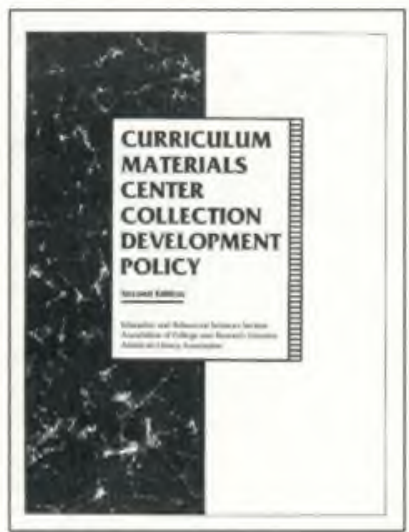




\section{State Education Documents:}

A State-by-State Directory for Their Acquisition and Use

EBSS Education-Related Government

Publications Subcommittee

This directory provides the means to access the large variety of state education documents available from government agencies. $\$ 21.95$; ACRL member $\$ 18.95,54 \mathrm{p}$.

0-8389-7327-2, 1989

\section{Western European Studies:}

Current Research Trends \& Library Resources

Eva Sartori, Ceres Birkbead, John Cullars, John Dillon, Thomas Killon, editors

Eleven research papers offer thoughtful synthesis, personal insight, and information useful for anyone dealing with recent scholarship in Western European studies. $\$ 32.95$; ACRL member $\$ 29.95,120 \mathrm{p}$. 0-8389-7461-9, 1990

\section{Ethnic Studies Reviews}

Publications in this series from CHOICE are compiled by the editors from reviews previously published in the magazine (volumes 27 through 29, Asian Americans through volume 30). Each collection provides the full text of the CHOICE review and author and title indexes. The editors consider these collections representative of the significant books that CHOICE reviewed in these ethnic areas. Order from CHOICE, 100 Riverview Center, Middletown, CT 06457 .

\section{Asian and Asian American Studies}

$\$ 20.00,605$ titles, $113 p$.

$0-8389-7691-3,1993$

\section{Latino Studies}

$\$ 20.00,525$ titles, 112p.

0-8389-7631-X, 1992

\section{African and African American Studies}

$\$ 22.00$, approximately 750 titles, $152 \mathrm{p}$.

0-8389-7691-1, 1992

\section{Native American Studies}

$\$ 15.00,278$ titles, 60p.

$0-8389-7632-8,1992$

\section{SPECIAL COLLECTIONS}

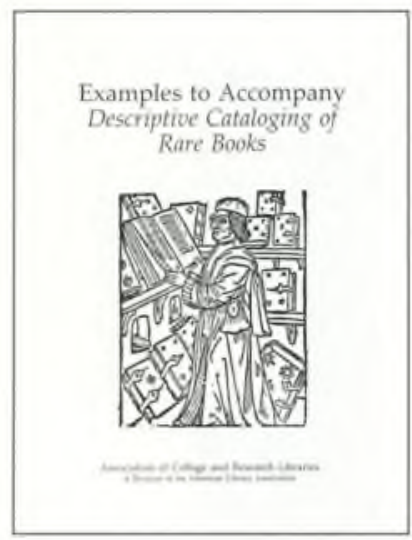

\section{Examples to Accompany Descriptive Caraloging of Rare Books}

Prepared by the Bibliographic Standards Committee of the Rare Books and Manuscripts Section

"The introduction is clear, the bibliography useful, the indexes exhaustive and the records themselves painstakingly accurate. In short, it is a model of its kind, and should be consulted not only by those cataloguers currently using the code but also all managing librarians considering its adoption."-Rare Books Newsletter $\$ 29.95$; ACRL members $\$ 23.95,148 p$. 0-8389-7672-7, 1993 


\section{Thesauri for Use in Rare Book and Special Collections Cataloging}

These thesauri were developed for use in MARC field 655 and 755. Each thesalurus provides standardized vocabulary for retrieving items by form and genre or by various physical chatracteristics which are typically of interest to special collections librarians.

Genre Terms (2nd ed.)

$\$ 21.95$; ACRL member $\$ 18.95$, 90p.

0-8389-7516-X, 1991

\section{Paper Terms}

$\$ 8.95$; ACRL member $\$ 7.50,52 \mathrm{p}$.

$0-8389-7427-9,1990$

\section{Type Evidence}

$\$ 8.95$; ACRL member $\$ 7.50,19 p$.

0-8389-7428-7, 1990

\section{Binding Terms}

$\$ 11.50$; ACRL member $\$ 9.50,37 \mathrm{p}$.

0-8389-7210-1, 1988

\section{Printing \& Publishing Evidence}

$\$ 8.95$; ACRL member $\$ 7.50,28 p$.

0-8389-7108-3, 1986

\section{Provenance Evidence}

$\$ 10.50 ;$ ACRL member $\$ 8.50,24 \mathrm{p}$.

0-8389-7239-X, 1988

\section{BIBLIOCRAPHIC INSTRUCTION}

\section{Sourcebook for Bibliographic}

\section{Instruction}

The Editorial Board of the Bibliographic Instruction Section

A working, desk-top tool for new and experienced bibliographic instruction librarians, the Sourcebook is practical and easy-to-use. Five essential topics are covered: learning theory, instructional design, teaching methods, evaluation, and administration. "Highly recommended for all institutions engaging in BI,"-Library Joumal

\$18.95; ACRL member \$16.95, 96p.

0-8389-7673-5, 1993

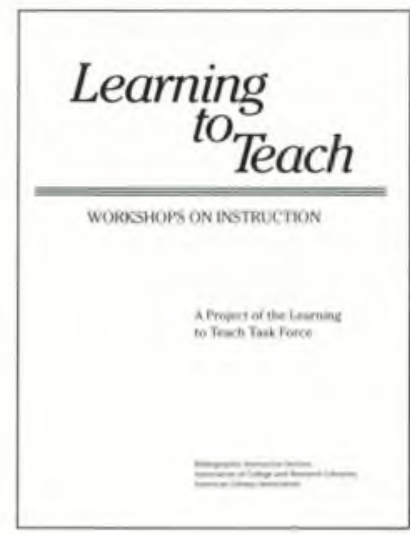

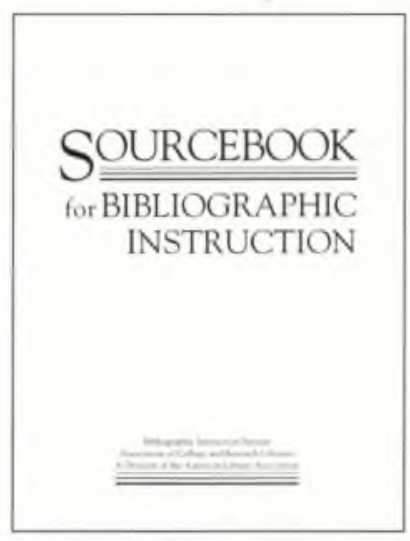

\section{Learning to Teach: Workshops on Instruction}

Nine workshops cover the basics inclucling clear, concise discussions of classroom techniques, new technologies, and instruction in a multicultural environment. This collection of workshops is designed to develop fundamental skills and addresses critical issues in bibliographic instruction. "Recommended for practitioners as well as academic, library school, and school library collections." - Library Journal

\$27.95; ACRL member \$24.95, 86p. 0-8389-7627-1, 1993 


\section{The Evolving Educational Mission of the Library}

Betsy Baker, Mary Ellen Litzinger, editors

Strategic issues which challenge the clevelopment of instructional programs in academic libraries and roles for librarians in the educational processes of their parent institutions. Academic librarians, library school educators, and higher education faculty and administrators will want this book. "Those excited about the information literacy movement will likely find this book inspiring." $-R Q$

$\$ 29.95$; ACRL member $\$ 19.95,202 p$.

0-8389-7584-4, 1992
Read This First: An Owner's Guide to the New Model Statement of Objectives for Academic Bibliographic Instruction

Carolyn Dusenbury, Monica Fusich, Kathleen Kenny, and Beth Woodard, editors

"...the MSO [model statement objectives] may serve as a checklist in evaluating existing $13 \mathrm{I}$ programs, developing educational goals when determining new programs, and determining whether such goals are being achieved."-Library Joumal $\$ 19.95$; ACRL member $\$ 16.45,72 p$. 0-8389-7548-8, 1991

\section{INFORMATION ACCESS}

\section{NEW!}

\section{Internet Resources: A Subject Guide}

Hugh A. Thompson, comp.

Newly updated articles originally appearing in CERL News that list information sources on the Internet, including gopher's, WwW, listservs, bulletin boards, discussion groups, online bibliographies, newsletters, and more. Sixteen diverse subject areas ranging from architecture to womens' studies.

Price forthcoming. $95 p$.

0-8389-7785-5, 1995

\section{NEW!}

\section{Vocational and Technical Resources for Community College Libraries}

\section{Mary Ann Laun, editor}

Annotated bibliographies presenting a collection of resources, both print and nonprint, that are needed to support a vocational and technical curriculum for a community college, or a vocational or technical institution. Useful to undergracluate students, vocational and technical students, librarians, faculty, and the general public looking for information on these programs' resources.

$\$ 95.00, A C R L$ member $\$ 85.00,622 p$

0-8389-7775-8, 1995

\section{NEW! \\ Science and Engineering Conference Proceedings:}

A Guide to Sources for Identification and Verification

Overview of the coverage and indexing of conference proceedings and papers in subject-oriented abstracting and inclexing services. A valuable working tool for the practicing librarian involved with public services for the scientific and engineering community.

Price forthcoming, $84 \mathrm{p}$. 0-8389-7790-1, 1995

\section{Guide to Searching the Bibliographic Utilities for Conference Proceedings}

Nirmala S. Bangalore, Judith A.

Carter, editors

A convenient guide detailing search strategies for finding conference proceedings in either RLIN, OCLC/PRISM, or WLN utilities.

$\$ 7.95$; ACRL member $\$ 6.95,15 p$.

0-8389-7734-0, 1994 


\section{Abstracting, Information}

Retrieval, and the Humanities:

Providing Access to Historical Literature Publications in Librarianship: No. 48 An examination of the qualities and functions of abstracts and the challenges involved in text conclensation.

Helen R. Tibbo

$\$ 35.00,276 \mathrm{p}$.

0-8389-3430-7, 1993

Scholarly Communication in an Electronic Environment: Issues for Research Libraries Robert Sydney Marlin, editor

Any academic librarian in a position to subscribe to, manipulate, or face the administrative issues of electronic media will find a timely base of information in this book. "Relevant to all persons interested in the development and management of research libraries." - JAL

\$28.95; ACRL member \$24.95, 136p.

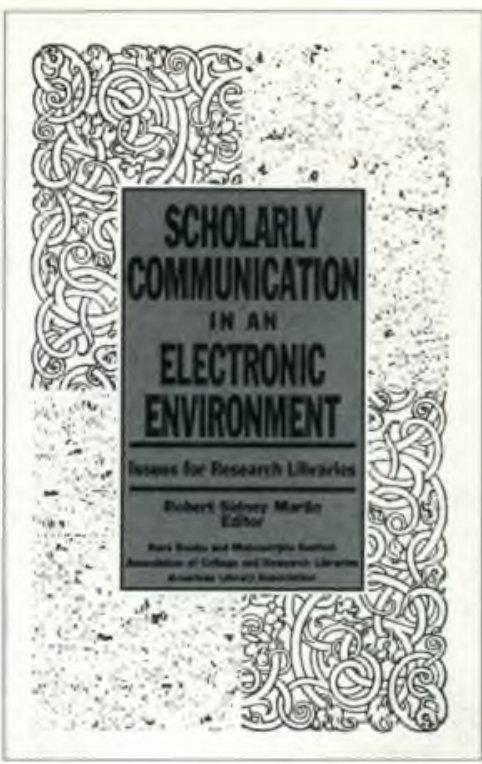

\section{Recruit a new member !}

\section{There's strength in numbers.}

Sign up new members and we all benefit.

Get the word out about the advantages of ACRL membership.

* Career information resources

* Awards and fellowships

* Publications

* Flectronic communications

* Continuing professional development
* Discussion groups

* Advocacy

* Sections

* Chapters

* Standards and Guidelines

\section{Help ACRL grow!}

Call Cheryl Bernero (312/280-2510)

at ACRL for membership materials. 


\section{STATISTICS}

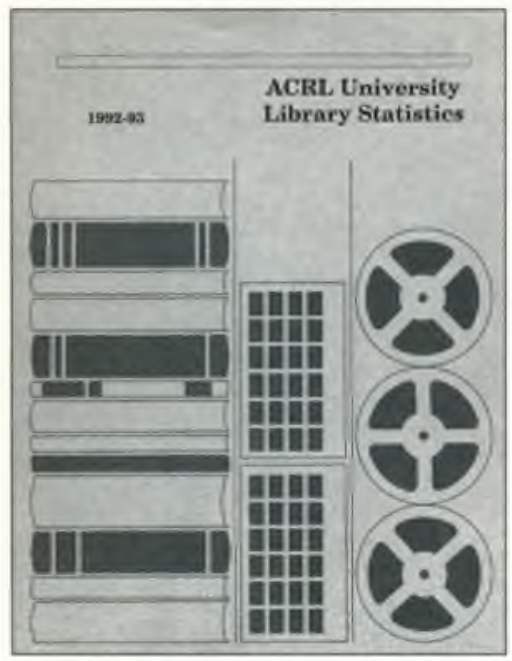

\section{NEW!}

\section{Continuity and Transformation:}

The Promise of Confluence

Proceedings of the Seventh National

Conference of the Association of

College and Research Libraries

Richard AmRhein, editor

Describes how librarians across the country are incorporating new and established technologies to enhance the teaching, learning, and research processes. Includes

54 refereed contributed papers and abstracts of 31 panel sessions.

Price forthcoming, 500p.

0-8389-7786-3

\section{Academic Libraries Achieving} Excellence in Higher Education:

Proceedings of the Sixth National Conference of the Association of College and Research Libraries Thomas Kirk, editor.

Practical examinations and solutions to current acaclemic library problems are included in 4 keynote addresses, 36 program reports, and 52 refereed contributed papers. "...an excellent professional development resource for librarians trying to keep current and for new librarians concerned about the profession."-JAI. $\$ 49.95$; ACRL member $\$ 44.95,522 \mathrm{p}$. 0-8389-7622-0, 1992

\section{ACRL University Library} Statistics, 1992-93

Library Research Center. Graduate School of Library \& Information Science, University of Illinois at Urbana-Champaign, comp.

Data from over 109 participating libraries Ljbrary categories inclucle collections, personnel, expenditures, and interlibrary loan. Institutional categories include degrees offered, enrollment size, and faculty size.

$\$ 69.95$; ACRL member $\$ 39.95,80 \mathrm{p}$. 0-8389-7738-3

\section{ACRL University Library Statistics, 1990-91}

Library Research Center, Graduate

School of Library E Information

Science, University of Illinois at

Urbana-Champaign. comp.

$\$ 69.95$; ACRL member $\$ 39.95,80 p$. $0-8389-7587-9,1992$

\section{ACRL/Historically Black Colleges \& Universities Library Statistics, 1988-89}

Robert E. Molyneux, comp. $\$ 35.95$; ACRL member $\$ 25.95,101 \mathrm{p}$. 0-8389-7547-X, 1991

\section{ACRL University Library Statistics, 1988-89 \\ Denise Bedford, comp.}

$\$ 49.95$; ACRL member $\$ 29.95,79 \mathrm{p}$. 0-8389-7446-5, 1990

\section{ACRL University Library Statistics, 1987-88 \\ Robert E. Molyneux, comp.}

$\$ 49.95$; ACRL member $\$ 29.95,79$ p.

0-8389-7288-8, 1989

\section{ACRL Academic Library}

Statistics, 1978/79-1987/88

(Diskettes)

\$59.95; ACRL member $\$ 49.95$

0-8389-7310-8, 1989 


\section{ORDER FORM}

1. Fill in your shipping and billing addresses.

Ship to:

Bill to:

\section{Indicate quantity of each item you wish to order.}

Abstracting, Info. Retrieval, $\$ 35.00$;

0.8389-3430-7

Academic Lib. Achieving Excellence,

$\$ 49.95 / 44.95 ; 0-8389-7622.0$

Academic Status, $\$ 10.95 / \$ 8.95$;

0.8389.7739.1

ACRL Stats 92/93, \$69.95/39.95:

$0.8389 .7738-3$

ACRL Stats $90 / 91$. \$69.95/39.95:

0.8389 .7587 .9

ACRL Stals 1988/89, \$49.95/

$29.95 ; 0-8389.7446-5$

ACRL Stats 1987/88, \$49.95/

29.95: $0.8389-7288.8$

ACRL Stats 78/79-87/88 (Diskelles).

$\$ 59.95 / 49.95 ; 0-8389.7310-8$

Annual Reports, \$21.95/18.75:

0.8389.7219.5

A-V Policies, \$21.95/18.95:

0-8389-7495.3

Binding Terms, \$11.50/9.50;

0-8389.7210.1

Books for College Libraries, $\$ 600$;

0-8389-3353-X

Collection Devel. Policies, \$26.95/

21.95; 0-8389-7295-0

Collect. Mgt. in Elect. Age, \$42.95/

$35.95 ; 0.8389-7737.5$

College Lib. Newsletters, \$18.95/

15.95; 0-8389-7445-7

C\&RL and C\&RL News, Index v. 41-50,

$\$ 29.95 / 25.95$; 0-8389-7487-2

Continuity $\&$ Trans., Price T.B.D.:

0-8389-7786-3

Curriculum Mat'ls Ctr. Dev., \$16.95/

14.95; 0-8389-7707-3

Database Searching in College

Libraries, \$29.95/24.95:

0.8389-7651-4
Dir. of Curriculum Center, $\$ 39.50$ /

32.95; 0-8389-7439-2

Discovering Librarians, $\$ 35,95 /$

\$31.95; 0-8389.7753.7

Emergency Planning, \$28.95/25.95:

0-8389-7710-3

Evolving Educational Mission, \$29.95/

19.95; 0.8389-7584-4

Examples to Accompany DCRB,

$\$ 29.95 / 23.95 ; 0-8389-7672.7$

Friends of College Lib. \$18.75/

$15.50 ; 0.8389 .7171 .7$

Formal Planning, $\$ 27.95 / \$ 24.95$;

0-8389-7743-X

Genre Terms, \$21.95/18.95;

0-8389-7516.X

Guide to Searching, $\$ 7.95 / \$ 6.95$;

0-8389-7734.0

HBCU Slats 88/89, \$35.95/25.95:

0-8389-7547-X

Interlibrary Loan in College Libraries,

\$34.50/28.75; 0-8389-7652-2

Inlernet Resources, Price T.B.D.;

0-8389-7785.5

learning to Teach, $\$ 27.95 / 24.95$;

0-8389-7627-1

Library Srves for Non-Affil. Patrons, $\$ 32.95 / 27.95 ; 0.8389 .7781 .2$

Managing Student Workers, \$29.95/ $\$ 25.95 ; 0.8389 .7752-9$

Measuring Acad. lib. Perf., $\$ 34.00$; 0-8389-0529.3

Measuring... (disk \& book), \$75.00; 0.8389.0542-0

Mission Statements, $\$ 21.95 / 16.50$; 0.8389.6944.5 
Paper Terms, \$8.95/7.50;

0.8389.7427.9

Performance Appraisal, \$18.95/

15.95: 0.8389.7444.9

Periodicals in College Lib., \$18.75/

15.45 ; 0.8389.7143-1

Preparing for Accredilation, $\$ 18.00$;

0-8389.0621.4

Printing \& Pub. Evidence, \$8.95/7.50;

0.8389.7108-3

Provenance Evidence, \$10.50/8.50;

0-8389-7239-X

Read This First, \$1975/16.45;

0.8389.7548.8

Recruiting Acad. Lib. Dir., \$18.95/

15.95; 0-8389.7484.8

Richard Garnell, $\$ 30.00$;

0-8389.0508-0
Scholarly Communication, $\$ 28.95$ /

24.95; $0.8389-7686.7$

Sci./Eng'g Conf. Proc., Price T.B.D.;

0.8389-7790-1

Sourcebook for B.I., \$18.95/16.95;

0.8389-7673.5

Staff Development, $\$ 22.95 / \$ 19.95$;

0.8389-7715.4

Stale Education Doc., \$21.95/18.95;

0-8389-7327.2

Type Evidence, \$8.95/7.50;

0.8389.7428.7

Vocational Technical Resources, \$95.00/85.00; 0-8389.7775.8

Western European Studies, $\$ 32.95 /$ 29.95; 0.8389.7461.9

Women's Studies Coll. Dev. Policies, $\$ 35.95 / 29.95 ; 0.8389 .7596-8$

\section{Indicate a subtotal and add appropri-} ate handling charges. Handling charges are $\$ 3.75$ for orders up to $\$ 19.99, \$ 1.75$ for $\$ 20$ to $\$ 49.99$; $\$ 6.50$ for $\$ 50$ to $\$ 74.99 ; \$ 7.50$ for $\$ 75$ to $\$ 149.99$, and $5 \%$ of total for orders above $\$ 150$.

s Subtotal

s Handling charges

5 Total

\section{Select method of payment.}

$\square$ Check/money order enclosed Charge my credit card: $\square$ MasterCard Card Number: Expires:

Signature

\section{Mail order to:}

ACRL, Attention: Hugh Thompson, 50 East Huron Street, Chicago, IL. 60611. For faster, more personal service, call toll-free (800) 545-2433, press 7, or fax (312) 836-9958.

Terms of Business Institutions and individuals may order on account, plus postage and handling. Prepayment should accompany individuals' orders of \$30 or less. Shipping and handling charges will be added to all orders. All prices are payable in US. funds, net 30 days. First price is list price.

Discounts. ALA personal and organizational members are eligible to receive a ten percent (1090) discount on ACRL materials (except subscription items). To receive the discount, give your membership number, and deduct the discount when preparing your orders. ACRL personal and organizational members receive 103096 discount on nonsubscription ACRL materials. Look for the ACRL. member price in this booklet. 


\section{OFFICIAL ACRL DOCUMENTS}

Indicate quantity of each item to be shipped.

\section{ACCESS}

Guidelines for the Preparation of Policies on Library Access CERL News, Dec. 1992. 10p. \$2.00

\section{AUDIOVISUAL}

Guidelines for Audiovisual Services in Academic Libraries CERL Neus, Oct. 1987. 4p. \$2.00

\section{BIBLIOGRAPHICINSTRUCTION}

Guidelines for Bibliographic Instruction in Academic Libraries CERL Neus, April 1977. 1p. $\$ 2.00$

Model Statement of Objectives for Academic Bibliographic Instruction

CERL News, May 1987. 6p. $\$ 2.00$

\section{COLLEGES \& UNIVERSITIES}

Guidelines for Branch Libraries in Colleges and Universities CERL Neus, March 1991 4p. $\$ 2.00$

Guidelines for Extended Campus Library Services

CERL Neus, April 1990, 3p, \$2.00 (also see CERL Neus Jan. 1993 p.7 for corrections)

The Mission of an Undergraduate Library: Model Statement

CERL Neus, Oct. 1987. 3p. \$2.00

Standards for College Libraries CERL Neus, April 1995. 12p. One copy free; additional copies $\$ 2.00$ each.

Standards for University Libraries CERL Neus, Sept. 1989. ACRL/ARL. 13p. Single copy free; additional copies $\$ 2.00$ each.

\section{COMMUNITY \& JUNIOR COLLEGES}

Standards for Community, Junior and Technical College Learning Resources Programs ACRL/AECT.

CERL. News, October 1994. 14p. Single copy free; additional copies $\$ 2.00$ each.

\section{PERSONNEL ISSUES \& FACULTY STATUS}

ALA-SAA Joint Statement on Access to Original Research Materials

CERI Neus, Dec. 1993, 2p. $\$ 2.00$

Guidelines for Academic Status for College and University Libraries

CERL News, March 1990, 2p, \$2.00

Joint Statement on Faculty

Status of College and

University Librarians

ACRL/AAUP/AAC. CERL News,

Feb. 1974. 1p. $\$ 2,00$

Model Statement for the

Screening \& Appointment of

Academic Librarians Using a

Search Committee

CERL Neus, Nov, 1992. 4p, \$2.00

Model Statement of Criteria and Procedures for Appointment, Promotion in Academic Rank, and Tenure for College and University Librarians CERL News, May 1987. 8p. \$2.00

Standards for Faculty Status for College and University Librarians

CERL Neus, May 1992. 2p. $\$ 2.00$

Guideline on Collective

Bargaining

CERL Neus, March 1993. 1p. $\$ 2.00$ 
Statement on the Terminal

Professional Degree for Academic Librarians

CERL Neus, Jan. 1975. 1p. $\$ 2.00$

Statement on the Certification \&

Licensing of Academic Librarians

GERI Neus, Nov. 1989. Ip. $\$ 2.00$

\section{RARE BOOKS, MANUSCRIPTS \& ARCHIVES}

Guidelines for Borrowing

Special Collections Materials for

Exhibition

CERL Neus, May 1990. 3p. \$2.00

Guidelines for the Loan of Rare and Unique Materials

CERI. Neus, May 1993. 3p. $\$ 2.00$

Guidelines for the Security of

Rare Books, Manuscripts, and

Other Special Collections

CERL Neus, March 1990. 5p. $\$ 2.00$
Guidelines on the Selection of General Collection Materials for Transfer to Special Collections, 2nd edition

CERL Neus, Dec. 1993. 4p. $\$ 2.00$

Guidelines Regarding Thefts in Libraries

CERL Neus, November 1994. 6p. $\$ 2.00$

Joint Statement on Access on Original Research Materials CERL. Neus, Dec. 1993. 3p. $\$ 2,00$

Relator Terms for Rare Book, Manuscript, and Special Collections Libraries

GERL Neus, Oct. 1987. 5p, $\$ 2.00$

Standards for Ethical Conduct for

Rare Book, Manuscript, and

Special Collection Librarians. with Guidelines for Institutional Practice in Support of the Standards, 2nd edition CERL Neus, April 1993. 9p. \$2.00

\section{Shipping address:}

Name:

Address:

\section{Mail order to:}

ACRL Official Documents

50 East Huron Street

Chicago, IL 60611-2795

or FAX: $312 / 280-2520$

Recent standards have been made available on the ALA/ACRL gopher. Gopher to "gopher.uic.edu, port 70".

Items on pages 13 and 14 may be photocopied for noncommercial purposes. 


\section{NEWS \& REVIEWS}

\section{Choice}

Book review journal of the Association of College and Research Libraries (ACRL).

Eleven issues per year (July/August combined).

Available by subscription only, $\$ 165 /$ year domestic rate; $\$ 187 /$ year foreign rate; single issues $\$ 20.00$ ISSN: 0009-4978

Also available as:

\section{Choice-Reviews-on-Cards}

Reviews from each monthly issue of Choice printed on $3 \times 5$ cards.

Available to Choice subscribers only for $\$ 245$ / year domestic rate; $\$ 265 /$ year foreign rate; sample box $\$ 25.00$. Order either Choice product from: Circulation Department, Choice, 100 Riverview Center, Middletown, CT 06457 (203) 347-6933

\section{Rare Books \& Manuscripts Librarianship}

A journal of theory and practice covering all aspects of special collections librarianship. Two issues/year $\$ 30.00$ U.S.; $\$ 35.00$ for Canada and Mexico; and all other countries $\$ 40.00$; single issues $\$ 15.00$ each. ISSN: 0884-450X.

\section{College \& Research Libraries}

Official journal of the Association of College and Research Libraries. Six bimonthly issues per year. Sent to ACRL members as a perpuisite of membership. Also available on subscription. $\$ 50.00$ per year in the U.S.; Canada and Mexico $\$ 55.00$ per year; and all other countries $\$ 60.00$; single issues $\$ 14.00$ each. ISSN: $0010-0870$.

\section{College \& Research Libraries News}

Official news magazine of the Associaltion of College and Research Libraries. Eleven issues per year (July/August combined). Sent to ACRL members as perquisite of membership. Also available on subscription

$\$ 35.00$ per year in the U.S.; $\$ 40.00$ per year in Canada and other PUAS countries; $\$ 45.00$ in other foreign countries; single issues $\$ 6.50$ each. ISSN: 0099-0086.

\section{College \& Research Libraries and College \& Research Libraries News, Index for Volumes 41-50 (1980-89) $\$ 29.95$; ACRL member $\$ 25.95,180 \mathrm{p}$. $0-8389-7487-2,1991$}

\section{ACRL APPROVAL PLANS}

ACRL publications provide practical ideas, tools, and methods for: management. bibliographic instruction, special collections, collection development, statistics, and research. The convenient and cost-cutting ACRL approval orcler plan provides automatic priority shipping of ACRL's new books at a $20 \%$ discount to ACRL members ( $10 \%$ to nonmembers).

There are two approval plan categories from which to choose:

- Plan P guarantees that you will automatically be sent all new ACRL publications including CLIP Notes. ACRL publishes approximately 5 to 6 new titles each year

- Plan PC is exclusively for titles in the CLIP Notes (College Library Information Packets) series. CLIP Nores collect data and sample documents from academic libraries to assist librarians in establishing or refining services and operations.

It's ealsy to enroll, Make your selection on the order form in this catalog. Or call or write the ACRL Publications Officer indicating the category you have chosen. ACRL/ALA. Approval Plan, 50 East Huron Street, Chicago, IL 60611; (800) 545-2433, ext. 2517 


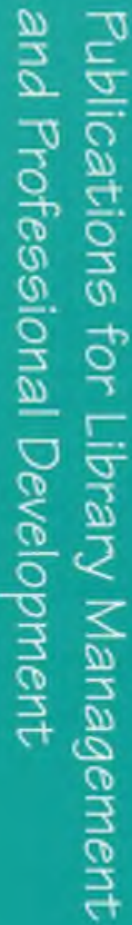

于े 
agement," "interdivisional collaboration," and "dealing with conflict." I strongly advocate ACRL's involvement in advancing members' organizational skills as well as library expertise.

\section{Meeting the needs of increasingly diverse user populations}

"By 2010, the combined multicultural populations in Arizona, California, Colorado, New Mexico, and Texas will become the numeric majority," stated Rebecca R. Martin in a recent article. ${ }^{1}$ There is no doubt that the faculty and student bodies academic librarians serve come from many different cultures and backgrounds. ACRL, along with individual libraries and librarians, has been highly sensitive to this issue. One of ACRL's goals this year is to strengthen the its com mitment to diversity. From articles such as Martin's, it is clear that some libraries have successfully coped with and fostered diversity in their institutions. However, in order to ensure that we provide responsive services to all of our users, there has to be a more concerted effort in our profession to address the many challenges of diversity, from sensitivity training to serving diverse user populations to recruitment of ethnic minorities into our ranks. ACRL can continue to play a major role in sharing successful strategies among its membership; coordinating efforts with other ALA-affiliated minority organizations, such as the Black Caucus of ALA and the Chinese-American Librarians Association; and collaborating with other higher education organizations interested in multiculturalism and diversity.

\section{Leadership: Within the higher education community}

Recent developments in electronic resources and new ways of seeking information have thrusted academic librarians onto the center stage of instruction on campus, whether we have faculty status or not. More than ever, academic librarians are on the front line teaching students and discipline-based faculty members how to navigate efficiently through the increasing array of information resources. Advances in information technology are changing the nature of the learning environment and prompting many educators to reevaluate the traditional methods of teaching and research. This presents a golden opportunity for academic librar- ians, who are well versed in issues and trends of scholarly communication and information technology, to contribute to the discussion and become key players in shaping the future of higher education.

To achieve such an important leadership role in the "business" of higher education, ACRL must actively continue to seek out links with other higher education organizations and scholarly associations, to create opportunities for dia-

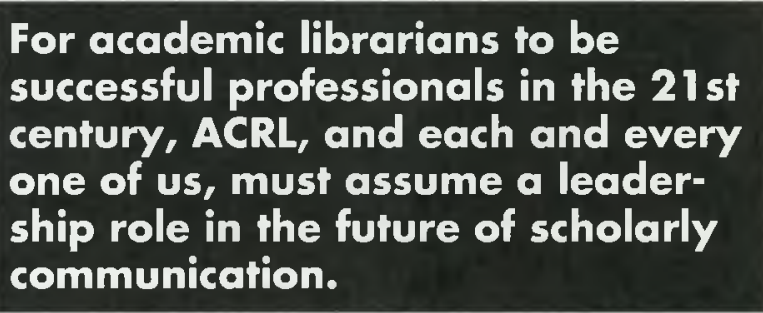

logue, and to assist its members in developing similar leadership roles on individual campuses. In recent years, the Professional Liaison Committee has accumulated an impressive record of linking with other organizations; but the field of higher education is vast, so there is much more linking and collaborating to do.

\section{Leadership: In the formulation of national information policies}

In 1994 the National Information Infrastructure (NII), the Clinton administration's plan to enhance American leadership in the information age, prompted many debates on telecommunications standards, security, and privacy on the "information superhighway"; intellectual property rights in the electronic environment; and the digitization of vast amounts of information for transportation over the superhighway. Each of these topics has policy implications that will greatly affect libraries and how we serve our faculty and students. ACRL must again play a leadership role in these discussions and shape the resulting national information policies to enhance the ability of academic libraries to serve their users.

\section{Become all we can be! ${ }^{2}$}

Shoshana Zuboff, in her book titled In the Age of the Smart Machine, stated:

"The questions that we face today are finally about leadership. Will there be leaders who are able to recognize the historical moment and the choices it presents? Will 


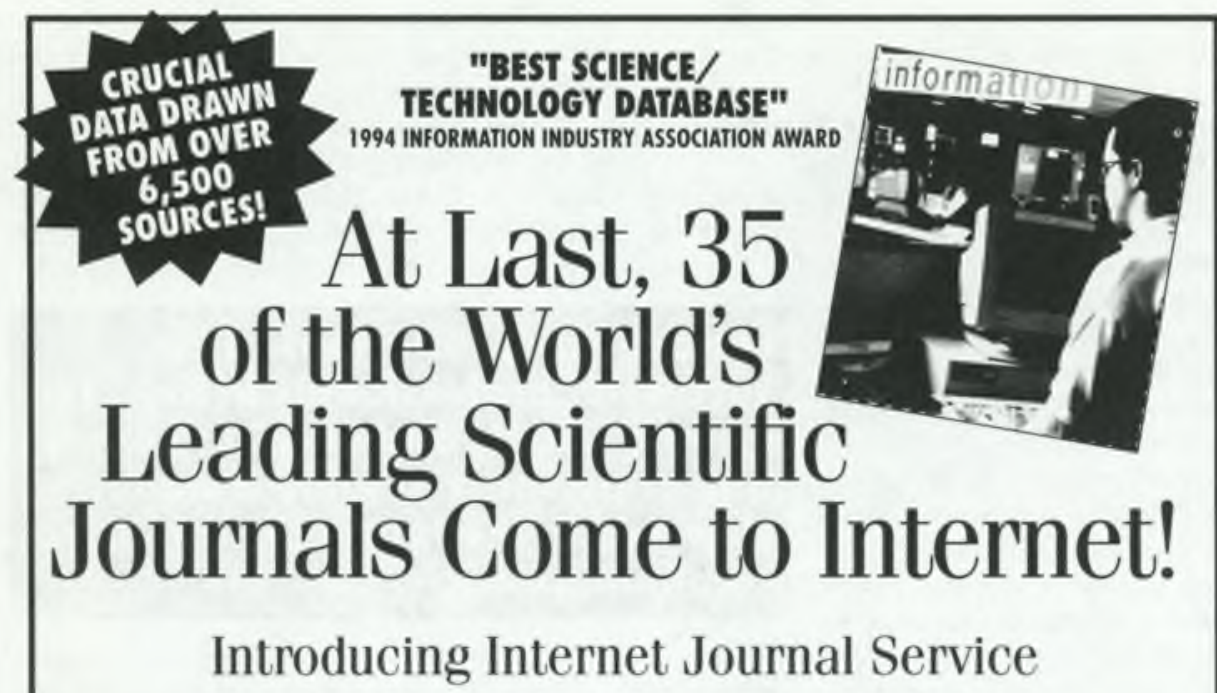

\section{ELECTRONIC ACCESS TO INFORMATION \\ PLUS PRINT JOURNALS IN ONE \\ UNPRECEDENTED SERVICE}

The new Internet Journal Service lets you obtain scientific and technical data foster and eosier than ever before. That's becouse electronic versions of all our print journals are now available on the Internet.

\section{CURRENT DATA PLUS FIVE YEARS OF BACKFILES}

Imagine. You have on instant Internet link to all of the data in Combridge Scientific's current journols. And you get monthly datobose updates (even before the journal goes to press).

What's more, you can pull up five years of backfiles. That's five years of the most important scientific abstracts drawn from more than 6,500 sources in:

- Environment \& Pollution - Biological Sciences: Biotechnology, Molecular Biology, Microbiology, Neuroscience, Zoology • Aquatic Sciences • Marine Biology \& Oceanography - Computer Science \& Engineering • And Much More.

\section{THE BEST WAY YET TO FIND SCIENTIFIC DATA}

With Internet Journal Service, you con subscribe to both the electronic version of our journaks and our regular print editions.
Of course, you con olso subscribe to either the electronic service or our print journols seporately. But whichever you choose, all the doto you wont will be ovoiloble in the format you prefer. And our convenient "search features" make finding critical data remarkably easy! We also provide you free WAlS search softwore.

\section{TRY THE IWTERNET JOURNAL SERVICE RISK-FREE!}

See for yourself. Access the Cambridge Scientific Abstracts home poge on World Wide Web (vio URL: http//www.cso.com/) and you can search a special one-year test file of any of our journols.

Or, better yet, pick a journal and try the full Internet Journal Service for 30 days... without risk or obligation. Then if you're not completely satisfied that this is a breakthrough in occess, you poy nothing.

It couldn't be easies. Just conlact

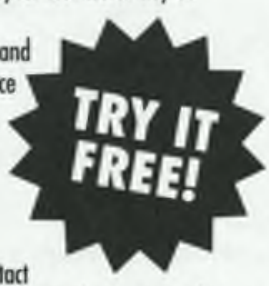
your preferred subscription agency or Cambridge Scientific to start your 30-day preview right now. And ask for our free 1995-1996 Cotolog.

\section{2a11)ifi]E Contoct Your Preferred Subsciption Agent or: CALL: 301-961-6757

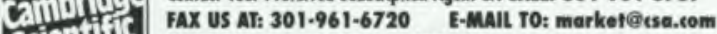 SCleflili CAMBRIDGE SCIENTIFIC ABSTRACTS ABSTRACTS 7200 WISCONSIN AVENUE, BETHESDA, MD 20814 USA}

\section{COME SEE US AT ACRL IN PITISBURGH!}

Stop by the Cambridge Scientific exhibit booth (408-412) for a special demonstrotion of the Internet Journal Service. 
they find ways to create organizational conditions in which new visions, new concepts, and a new language of workplace relations can emerge? Will they be able to create organizational innovations that can exploit the unique capabilities of the new technology and thus mobilize their organization's productive potential to meet the heightened rigors of global competition?"3

For academic librarians to be successful professionals in the 21st century, ACRL, and each and every one of us, must assume a leadership role in the future of scholarly communication.

\section{Notes}

1. Rebecca R. Martin, "Changing the University Climate: Three Libraries Respond to Multicultural Students," Joumal of Academic Librarianship 20 (March 1994): 2-9.

2. A phrase borrowed from Richard $M$. Dougherty's final editorial for the Journal of Academic Librarianship (January 1994): 355.

3. Shoshana Zuboff, In the Age of the Smart Machine: The Future of Work and Power (New York: Basic Books, 1988), p. 12.

\section{WILLIAM MILLER}

Academic and research librarians expect a lot from ACRL, and it is remarkable the degree to which ACRL (to which most academic librarians do not even belong) is nevertheless able to meet the needs of all of us, from promulgating standards to providing publications to helping our institutions fill positions. It is truly remarkable how much the staff and the membership together are able to accomplish. Strong and competent leadership has positioned the association well, both financially and organizationally within ALA. Still, there will be inevitable challenges to face in the years ahead, especially as nationwide resources become ever more constrained.

\section{The effects of technology}

We are all interested in technology, and also worried about it. At best it can revitalize and revolutionize our profession; at worst it can marginalize us or even eliminate not only librarianship but also much of academia as we currently know it. Our leaders have done well in setting up electronic means of communication and maintaining ACRL's membership in the Coalition for Networked Information, but we probably need a more concerted effort to anticipate the effects of changing technology on the profession of academic and research librarianship. I would set up a task force on possible information futures to advise the Board and help inform structural change in the association. The information age is still being invented. Just as we need to keep aware of it in our individual institutions, ACRL must plan to help represent a rapidly changing profession.

\section{Reinventing the organization}

Meanwhile, we need to consider a streamlining of ACRL, and a better articulation of our relationship with the rest of ALA. We do a fairly good job of eliminating committees that have outlived their usefulness, and we certainly want to give people with special interests a chance to fulfill their needs. However, it is far too easy to be so wrapped up in committee meetings (I counted about 350 such ACRL meetings in Philadelphia) that one has no time to attend programs, even ACRL programs. There is little time, in practical terms, for anyone seriously committed to ACRL business to function within the rest of ALA in any significant way.

We need to make significant time for ACRL members to attend non-ACRL events; participate in programs of other divisions; learn from and support our vendors at the exhibits; and simply enjoy the particular city we are visiting. We can never fully resolve this problem, but I would move to limit committee "sprawl"; limit units' programs substantially, perhaps offering them on a rotating basis; and explore the combining of ACRL units with similar groups in other divisions, creating "window" committees and programs which are appointed by and serve the needs of more than one division. The ALA PLAN listserv, devoted to joint programming, is a good idea. Anything we can do to reduce duplicative programming must be pursued.

\section{Effect of national conferences}

As part of its new planning process, the Board needs to consider fully the effect that our new every-other-year National Conference schedule will have on ACRL. We have not integrated the National Conference at all into our ongoing activities, and we may not be able to, but the increased frequency of this conference, combined with possible changes in ALA's programming (including possible elimination of the annual conference every other year, as suggested in the ALA self-study) make it impera- 
tive that we consider ACRL's programming as a totality, and stop thinking of the National Conference as an unrelated add-on.

\section{Continuing education}

The rather sudden elimination of ACRL's formal continuing education (CE) program several years ago weakened the association, in my view. The program as formerly constituted may have been costly and ineffective, but ACRL should offer some kind of formal CE program. It might be possible to substitute $\mathrm{CE}$ for some of our usual ALA programming (three speakers-one good, one bad, one horribly bad) and institute a tracked and progressive $C E$ program which people could choose either to attend for free or register and pay for on a formal basis. The National Conference would be a good venue for formal $\mathrm{CE}$, and the "Institutes" model followed by other divisions might also bear consideration.

\section{Budgetary needs}

ACRL is in a relatively strong financial position, but finances are still somewhat uncertain from year to year. Nevertheless, a large fund balance is required by

ALA as a condition for mounting national conferences. The increased frequency of the national conferences, combined with

ALA's accounting rules which recognize no revenue until earned, will mean that most of the cost of mounting a national conference will now have to be borne during a two-year rather than a three-year cycle. Meanwhile, the cost of basic membership services is barely covered by member dues, now the lowest of any division.

For these reasons, even if new services are not added, it is inevitable that a dues increase must be considered. Paradoxically, however, I would urge that a significant portion of any new revenue be added to ACRL's Endowment Fund to hold down the need for future dues increases and provide an increased, steady, and secure portion of the association's budget in future years.

\section{Racial and ethnic diversity}

To have a profound effect on recruitment of minorities into our libraries, we would have to have a great impact on factors over which li- brarians generally have no direct control-so we may be working at the margins here. Nevertheless, we must increase internships and mentor programs to help us affect the career choices of high school, college, and library school students. Cooperation with overall ALA efforts focusing on the image of the profession, and ACRL's own task force on certification may have long-term impacts on our ability to recruit. More importantly, the cliches of the "information highway," and the reality of our job duties if we can communicate them effectively, may ultimately work to our advantage in helping to make academic and research librarianship a more attractive career alternative for all racial and ethnic groups. One live demonstration of public telecomputing at a high school might be worth many thousands of words in communicating the excitement we naturally feel about our profession.

\section{Contact with other professionals}

Visibility in other professional associations may also help us with minority recruitment. For this and many other reasons, we need to form coalitions with professional groups outside of librarianship. Talking amongst ourselves can take us only so far. Thanks to current strong leadership we have a rejuvenated effort through the National Coalition on Information Literacy to reach out nationwide in this area. We must reach out to professional associations in a variety of areas that interest them, from technology and the bibliographic control of their literatures to the lifelong learning needs of their members. Academic and research librarians cannot stand as an island apart from the world in which we work. The formal liaisons whom we choose will be a part of this effort, but the contact must reach down further into our association, and theirs.

\section{Leadership within ACRL}

ACRL is a large and complex organization, and it exists in an even more complicated environment, both within ALA and outside of it. Additional training for effective leadership within ACRL is essential. Leaders must act as spokespersons for the organization and for the overall profession, as well as managers and re- 
shapers of the association itself. Recent initiatives to improve leadership include establishment of a listserv for elected leaders, and formal training and planning sessions on Friday aftemoons for elected leaders during ALA. These worthwhile efforts merit expansion, perhaps through a continuing education effort for a larger share of the membership. We must prepare ourselves to be leaders.

When it comes to running for vice-president/president-elect of ACRL, however, how does one prepare? My experience as chair of the Bibliographic Instruction Section and of the Choice Editorial Board, as president of the Michigan ACRL Chapter, and as a member of ACRL's Planning and Budget committees have exposed me to a significant percentage of ACRL's many facets, especially because they have inevitably meant ex officio involvement in many other areas such as conference programming, publications, and Chapters Council. My work at small colleges and large universities has exposed me to most of the work environments in which our members move. If I merit this office, it is only because I have experienced ACRL under various conditions for the past twenty years, and understand something about how ACRL relates to the needs and experiences of the average member.

We are entering a new era in which competition for reduced resources in higher education will be intense and the basic nature of the profession will be altered. If elected, I will try my best to keep the organization vital and represent your needs during this crucial transitional age.
(Scratch paper cont. from page 160)

ated and further reduced them to a less cumbersome quarter-page size. They intentionally look like simple forms, and yet they are still designed to teach unobtrusively the step-bystep process. We print them on the blank side of used paper and place the PAN form alongside the scratch paper that is used for writing down call numbers of books, around the OPAC terminals, and at all public service desks. The index form is placed near indexes in place of scratch paper.

One possible drawback to the forms is that, because of their simplicity, the patron is not prompted to write down all of the information required for interlibrary loan. We have decided to go with simplicity over thoroughness for a number of reasons: it serves our purpose of teaching the process; a simpler form is more likely to be used; its small size makes it easy to distribute; and it is fairly easy for patrons to retrace their steps and get additional information if needed.

We maintain the flexible attitude that these forms can easily be changed when new or better ideas are developed. With their adoption, we've seen fewer incomplete citations. Patrons have accepted them

Form 2. as useful tools and are beginning to ask us for them. We believe that the forms are instructional as well as convenient, and that they encourage users to be independent without pedantry on our part.

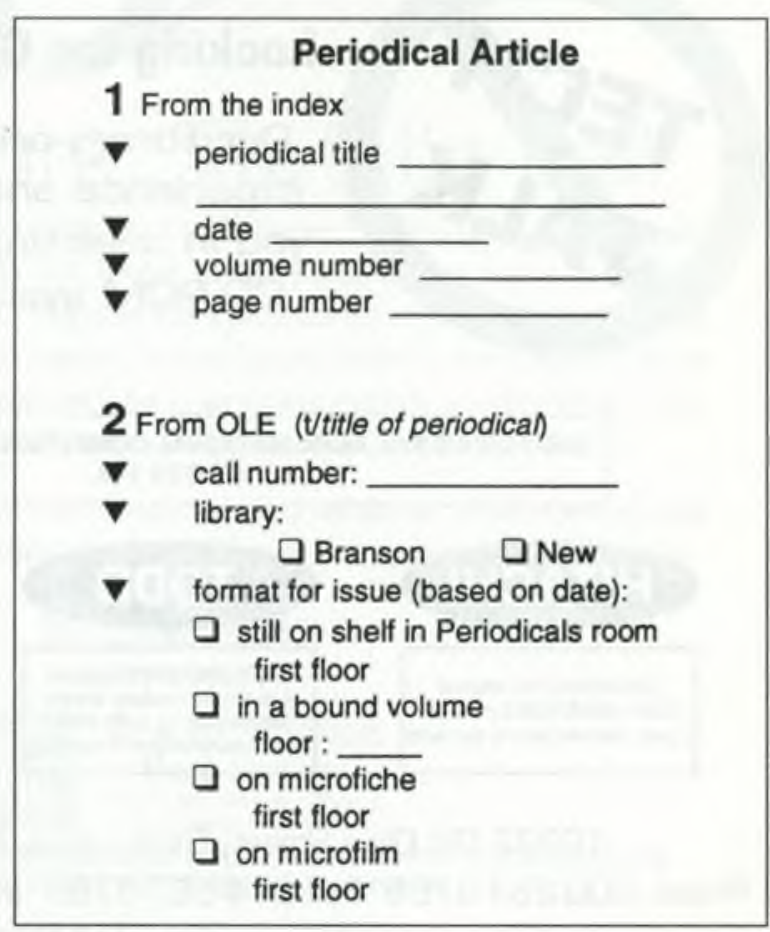



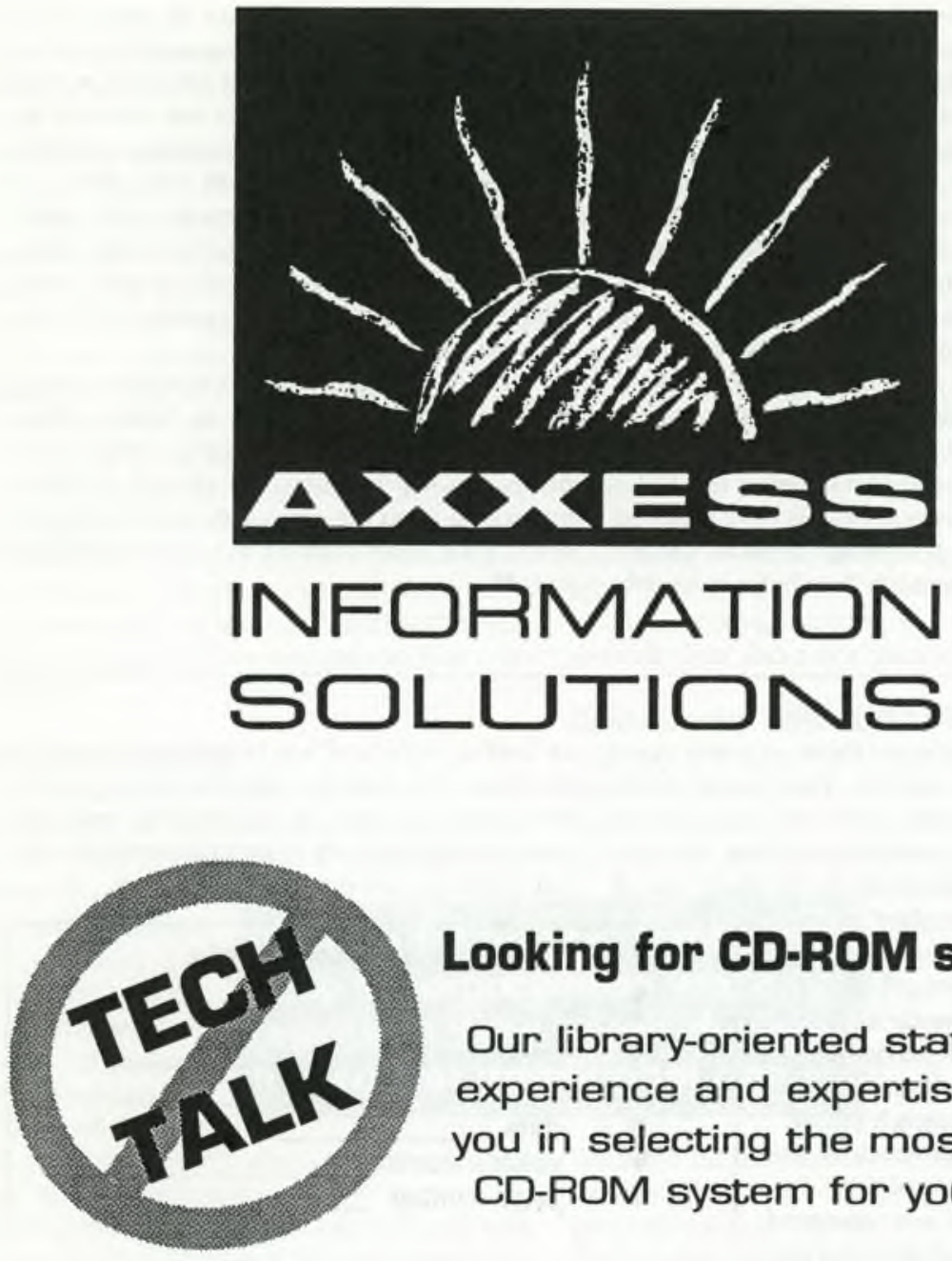

\section{Looking for CD-ROM solutions?}

Our library-oriented staff has the experience and expertise to guide you in selecting the most effective CD-ROM system for your library.

\begin{tabular}{c}
\hline $\begin{array}{l}\text { VISIT US AT THE ACRL NATIONAL CONFERENCE IN PITTSBURGH } \\
\text { BOOTH } 143\end{array}$ \\
\begin{tabular}{|c|c|c|} 
CDR-6700/6750 internal \\
2 year-1900S/1950S external
\end{tabular} \\
$\begin{array}{c}\text { TCDR-2XM/2XMS external } \\
4108 \text { drive modular towers } \\
\text { Cabinets for up to } 64 \text { drives } \\
3 \text { year manufacturer's warranty }\end{array}$ \\
\hline
\end{tabular}

10332 Old Olive Street, Saint Louis, Missouri 63141

Phone 800-264-3799 Fax 314-567-3798 Internet: AXXESS@MLNC.COM

- A subsidiary of MLNC * 

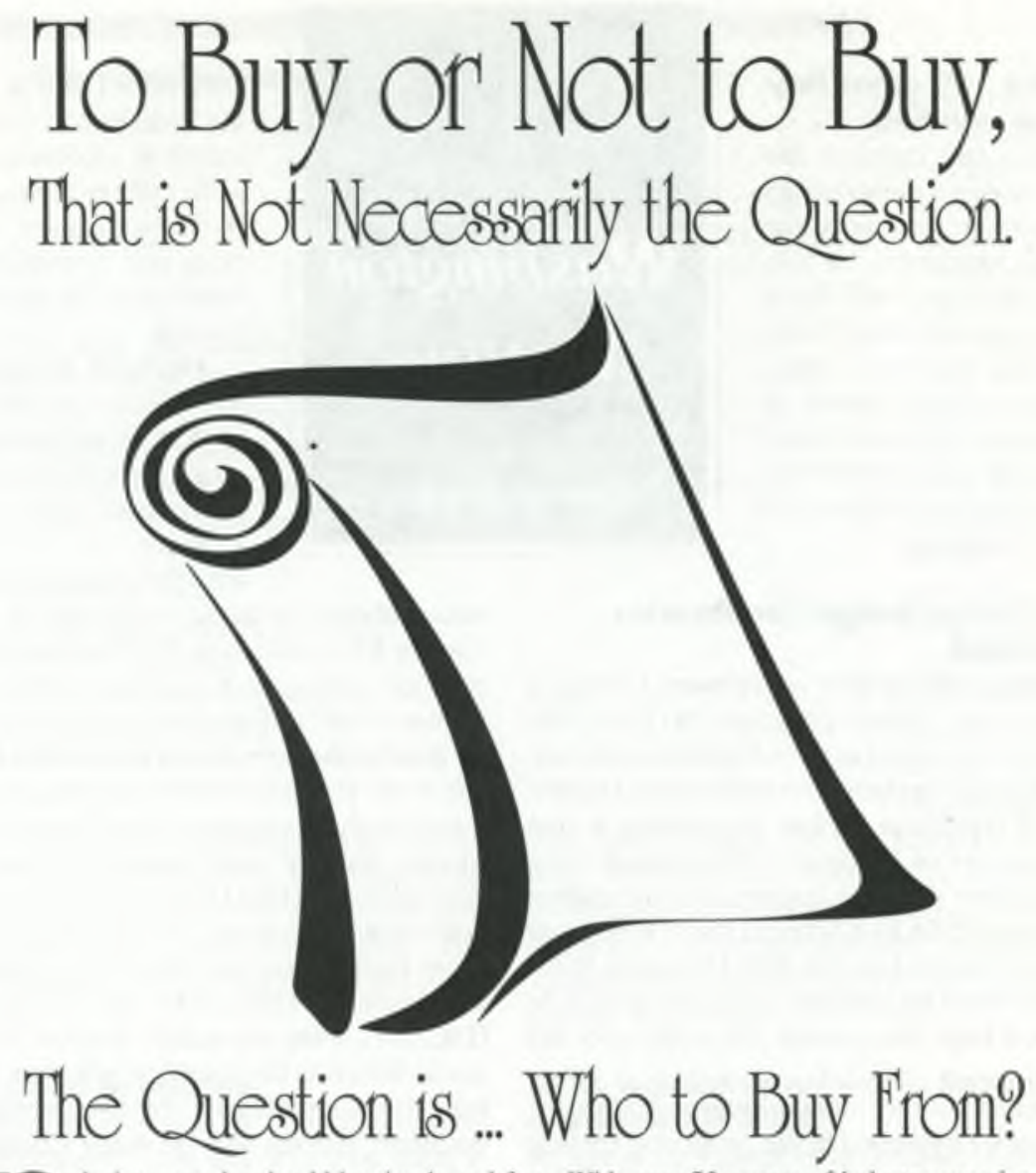

D

lacing an order should be simple and fast. With over fifty years of industry experience, when you place an order with Brodart, you are placing an order with a leader in the academic library market. Your order will be processed quickly and efficiently. You may place an order by mail or with our electronic ordering system. Orders are also accepted via fax or internet. If the title you have requested is not in our existing extensive inventory for immediate shipment, your titles will be ordered from the publisher immediately, regardless of quantity.

It is definitely not "nobler in the mind to suffer the slings and arrows" of ordering from other vendors. Let Brodart Academic Book Services assist you in your unending quest of where to buy. Call us today.

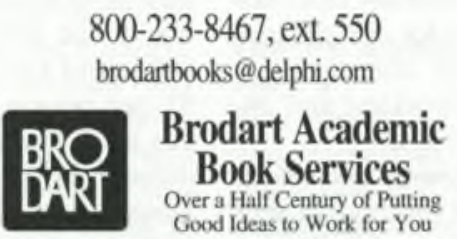

61885 - BRODART CO - AUTOUATION + BOOKS + FURNTURE - SUPPUES - 500 ARCH ST, WLLAMSPORT, PA 17705 + (717) 326-2461 + FAX BO0-999-6799 BRODART, LTD, 109 ROY BLVD, BRANTFORO, ONTARIO NSRTK1 • FAX 800-363-0483 